\title{
Physico-chemical Properties of Grape (Vitis vinifera L.) Pomace Fortified Drinkable Yoghurt
}

\author{
S. Subhashini*, D. Baskaran, B. Dhanalakshmi, B. Murugan and \\ Ayyavoo Preamnath Manoharan \\ College of Food and Dairy Technology, Koduveli, TANUVAS, Chennai-52, India \\ *Corresponding author
}

\section{A B S T R A C T}

\begin{tabular}{|l|}
\hline Ke y w o r d s \\
Waste, Grape \\
pomace, Powder, \\
Drink, Yoghurt, \\
Fermented product \\
\hline Article Info \\
\hline $\begin{array}{l}\text { Accepted: } \\
\text { 20 April } 2018 \\
\text { Available Online: } \\
\text { 10 May } 2018\end{array}$ \\
\hline
\end{tabular}

The most effective approach for food waste management is the source of minimization and recovery of by-products. The components present in food waste contribute to high level of nutrients, namely proteins, lipids, carbohydrates, fibres, antioxidants, polyphenols etc. The waste obtained during processing of grapes (Vitis vinifera L.) includes pomace, can be used in foods which are rich in nutritional and functional properties. Therefore utilization of waste from grape processing into preparation of dairy products which is of low cost raw material is presented in this study. This research was conducted to explore the possibility of utilization of grape pomace obtained during grape juice extraction for the preparation of value added dairy product viz. Drinkable yoghurt. The obtained grape pomace was dried using solar drier at $65^{\circ} \mathrm{C}$ for 6 hours and made into powder. The drinkable yoghurt was prepared to which the grape pomace powder was added at different levels of treatment $\left(\mathrm{PT}_{0}, \mathrm{PT}_{0.5}, \mathrm{PT}_{1.0}\right.$ and $\left.\mathrm{PT}_{1.5}\right)$. The physiochemical properties of drinkable yoghurt samples include moisture, $\mathrm{pH}$, titratable acidity, total solids, viscosity, fat and total dietary fibre were determined. Based on the physico-chemical results and sensory attributes the suitable treatment was taken for development of drinkable yoghurt.

\section{Introduction}

Grape pomace is widely accumulated in production belts especially arising from Vitis vinifera L. seeded variety during trimming and grading of bunches for quality assurance. It is estimated that about $20 \%$ of grapes are discarded and disposed off with no established waste reutilization in place. Grape pomace comprises of 2-3 seeds with outer pericarp which possess valuable bioactive polyphenols viz., resveratrol, catechin, epicatechin and anthocyanin in that order of occurrence. Therapeutic properties of grape pomace are not unraveled for its reuse in pharmaceutical and nutraceutical industries especially its application in food processing sector.

Globally, India ranks $10^{\text {th }}$ position in the production of grapes. The major grape producing countries are China, France, and Italy. The crop ranks fifth in India on the basis of agricultural productivity. $80 \%$ of total production of grapes in India comes from Maharashtra followed by Karnataka and Tamil 
Nadu (Ghosh et al., 2017). It is mainly grown for wine making, raisin making and for consumption as a fresh table grapes throughout the world.

In this study, the process of development of food novelties with grape pomace waste, it has been substituted in the form of powder for fortification of drinkable yoghurt. The physico-chemical properties and sensory attributes of drinkable yoghurt were studied.

\section{Materials and Methods}

The grape (Vitis vinifera L.) cultivar used in this study is Muscat Hamburg (Panneer/ Gulabi) variety, procured from Koyambedu market, Chennai. The selected grapes were washed in potable water to remove soil particles, dirt, etc. to obtain good quality grape pomace.

The grapes were handpicked from the clusters and the stems were removed carefully. The berries were rinsed with distilled water, dried with filter paper, crushed to obtain pomace. The wet grape pomace was dried in a solar drier at $60-65^{\circ} \mathrm{C}$ for 6 hours and ground into fine powder using a domestic food processor to obtain homogenized grape pomace powder (GPP).

Fortification of drinkable yogurt with grape pomace powder

Drinkable yoghurt is a network of proteins with interstitial space containing the liquid phase and void spaces in which starter culture (Streptococcus thermophiles, Lactobacillus delbrueckii spp. Bulgaricus) is present.

After incubation, the coagulum of stirred yoghurt is fragmented up mechanically before cooling and packaging, thus inducing considerable changes in the rheological properties.
The flow chart for the preparation of Drinkable Yogurt incorporated with grape pomace powder is given in Figure 1 (De, 1980).

Physio-chemical properties of fortified drinkable yoghurt

\section{Moisture content}

The moisture content of the milk beverage was determined by the AOAC (2007) method. About $5 \mathrm{~g}$ of the samples was weighed in to a pre-weighed clean petri dish and was placed in a hot air oven maintained at $105-110^{\circ} \mathrm{C}$ for 6 hours. After drying the petri dish was cooled in a desiccator and weighed. This was repeated until a constant weight was obtained. Moisture was expressed in percentage.

Moisture content $(\%)=\frac{\text { Moisture loss }(\mathrm{g})}{\text { Weight of the sample }(\mathrm{g})} \times 100$

\section{Titratable acidity}

Titratable acidity (TA) of samples was determined by visual titration method (Ranganna, 1986).About $1 \mathrm{~g}$ each of sample was mixed with warm water and volume was made up to $10 \mathrm{ml}$ in $100 \mathrm{ml}$ conical flask. The flask was shaken vigorously and filtered. The filtrates were titrated against $0.1 \mathrm{~N} \mathrm{NaOH}$ using phenolphthalein as an indicator. Per cent acidity was calculated using the following expression.

Titratable acidity $(\%$ of lactic acid $)=\frac{0.0090 \times V \text { Volume of } \mathrm{NaOH} \text { used }}{\text { Weight of the sample }} \times 100$

\section{pH}

A $\mathrm{pH}$ meter is an electronic instrument used for measuring the $\mathrm{pH}$ (acidity or alkalinity) of a liquid (through special probes are sometimes used to measure the $\mathrm{pH}$ of semi-solid substances). A typical $\mathrm{pH}$ meter consists of a 
special measuring probe (a glass electrode) connected to an electronic meter that measures and displays the $\mathrm{pH}$ reading. The $\mathrm{pH}$ meter was calibrated with commercial buffer solutions at $\mathrm{pH} 9.1$ and 4.0 before measurement. About $10 \mathrm{ml}$ sample was inserted with a $\mathrm{pH}$ electrode and $\mathrm{pH}$ was recorded after stabilization.

\section{Total solids}

The total solid content (\%) of the milk beverage was calculated by using the formula:

\section{Total Solids $(\%)=100$-Moisture Content}

\section{Viscosity}

Viscosity of the milk beverage was measured with a Rotational Viscometer (Cole-Parmer, India) using Spindle \#3.

\section{Fat}

The fat content of grape pomace fortified drinkable yoghurt were determined by solvent extraction method using Soxplus apparatus and hexane is used as a solvent (AOAC, 1990).

\section{Total dietary fibre}

Total Dietary fibre (DF), including soluble (SDF) and insoluble dietary fibre (IDF) fractions, was analysed by the enzymaticgravimetric method (AOAC 991.43).

\section{Sensory evaluation}

Sensory evaluation of prepared milk beverage using 9- point Hedonic scale (Larmond, 1977) was carried out by panel of judges comprising of six members. All the samples were appropriately coded before subjected to sensory evaluation.

\section{Statistical analysis}

The data obtained in all the experiments were analyzed statistically by applying one way ANOVA in IBM SPSS® software (version 20.0) for windows as per the standard procedure of Snedecor and Cochran, 1994.

\section{Results and Discussion}

\section{Fortification of drinkable yoghurt with grape pomace variants}

Grape pomace powder (GPP) was included at different levels $(0.5,1.0$ and 1.5 per cent $)$ in drinkable yoghurt. $\mathrm{PT}_{0}$ drinkable yoghurt was used as control in comparison with grape pomace fortified drinkable yoghurt. Different physicochemical properties were analysed and based on sensory analysis using 9 - point hedonic scale, 1.0 percent of grape pomace powder fortified drinkable yoghurt were exhibited higher level of consumer acceptance.

\section{Physio-chemical properties of fortified drinkable yoghurt}

Physio-chemical properties of fortified drinkable yoghurt were highly significant $(\mathrm{p}<$ $0.05)$ among treatments that are presented in Table 1.

\section{Moisture content}

Grape pomace variant fortified yoghurts had the low moisture values compared to the control yoghurt. This was dependent on the proportion of milk to grape pomace used. The moisture content of the yoghurt samples fell within the range of most commercial yoghurts (80-87 per cent). The results of the present study were in agreement with Maurya (2016) who examined moisture content of guava seed powder fortified yoghurt. 
Table.1 Evaluation of physico-chemical properties of drinkable yoghurt fortified with grape pomace powder

\begin{tabular}{|l|c|c|c|c|c|}
\hline \multicolumn{1}{|c|}{ Drinkable Yoghurt } & \multicolumn{5}{c|}{ Grape pomace powder (GPP) } \\
\cline { 2 - 6 } & PT $_{\mathbf{0}}$ & PT $_{\mathbf{0 . 5}}$ & PT $_{\mathbf{1 . 0}}$ & PT $_{\mathbf{1 . 5}}$ & F value \\
\hline Moisture Content & $86.50^{\mathrm{c}} \pm 0.00$ & $86.30^{\mathrm{bc}} \pm 0.07$ & $86.10^{\mathrm{ab}} \pm 0.07$ & $85.99^{\mathrm{a}} \pm 0.02$ & $19.141^{* *}$ \\
\hline Titratable acidity (\%) & $0.812^{\mathrm{a}} \pm 0.00$ & $0.834^{\mathrm{b}} \pm 0.00$ & $0.845^{\mathrm{c}} \pm 0.00$ & $0.856^{\mathrm{d}} \pm 0.00$ & $199.76^{* *}$ \\
\hline pH & $4.37^{\mathrm{c}} \pm 0.00$ & $4.36^{\mathrm{c}} \pm 0.01$ & $4.34^{\mathrm{b}} \pm 0.01$ & $4.32^{\mathrm{a}} \pm 0.01$ & $14.75^{* *}$ \\
\hline Total solids (\%) & $13.5^{\mathrm{a}} \pm 0.00$ & $13.7^{\mathrm{b}} \pm 0.07$ & $13.9^{\mathrm{c}} \pm 0.07$ & $14.01^{\mathrm{c}} \pm 0.02$ & $19.14^{* *}$ \\
\hline Viscosity (cP) & $190.00^{\mathrm{a}} \pm 0.15$ & $416.00^{\mathrm{b}} \pm 0.07$ & $440.00^{\mathrm{c}} \pm 0.47$ & $460.00^{\mathrm{d}} \pm 0.17$ & $221247.664^{* *}$ \\
\hline Fat (g) & $3.07^{\mathrm{a}} \pm 0.08$ & $3.69^{\mathrm{b}} \pm 0.14$ & $3.81^{\mathrm{c}} \pm 0.014$ & $4.01^{\mathrm{d}} \pm 0.016$ & $8.861^{* *}$ \\
\hline Total dietary fibre (\%) & $0.00^{\mathrm{a}} \pm 0.00$ & $0.55^{\mathrm{b}} \pm 0.00$ & $1.01^{\mathrm{c}} \pm 0.00$ & $1.55^{\mathrm{d}} \pm 0.00$ & $43569.167^{* *}$ \\
\hline
\end{tabular}

Average @ 6 trails. ** Highly significant $(\mathrm{P}<0.01)$ difference, * Significant $(\mathrm{P}<0.05)$ difference, NS- No Significant ( $\geq 0.05$ ), Different upper case superscripts in a same column differ significantly $\mathrm{P} \leq 0.01, \mathrm{PT}_{0}-$ control, $\mathrm{P}$ Powder, T-treatments

Fig.1 Flow chart for the preparation of drinkable yogurt

$$
\text { Toned milk }
$$

(3\% Fat and $8.5 \%$ S.N.F)

Addition of skim milk powder (4\%)

Addition of sugar (5\%)

Filtration/Clarification $\left(35-40^{\circ} \mathrm{C}\right)$

Pre-heating,the $\operatorname{mix}\left(60^{\circ} \mathrm{C}\right)$

Homogenization (2500 psi)

Pasteurization $\left(85^{\circ} \mathrm{C} / 30 \mathrm{~min}\right)$

$$
\text { Cooling }\left(43-44^{\circ} \mathrm{C}\right)
$$

Inoculation $(2 \%)$

Incubation ( $41-42^{\circ} \nsubseteq / 3$ hour) $(0.75 \%$ T.A.)

Cogoling

Addition of Grape pomage powder(0.5, 1.0 and 1.5\%)

Blending

Cooling and $\downarrow$ storage $\left(5-7^{\circ} \mathrm{C}\right)$

Fig.2 Sensory profile of the grape pomace fortified drinkable yoghurt

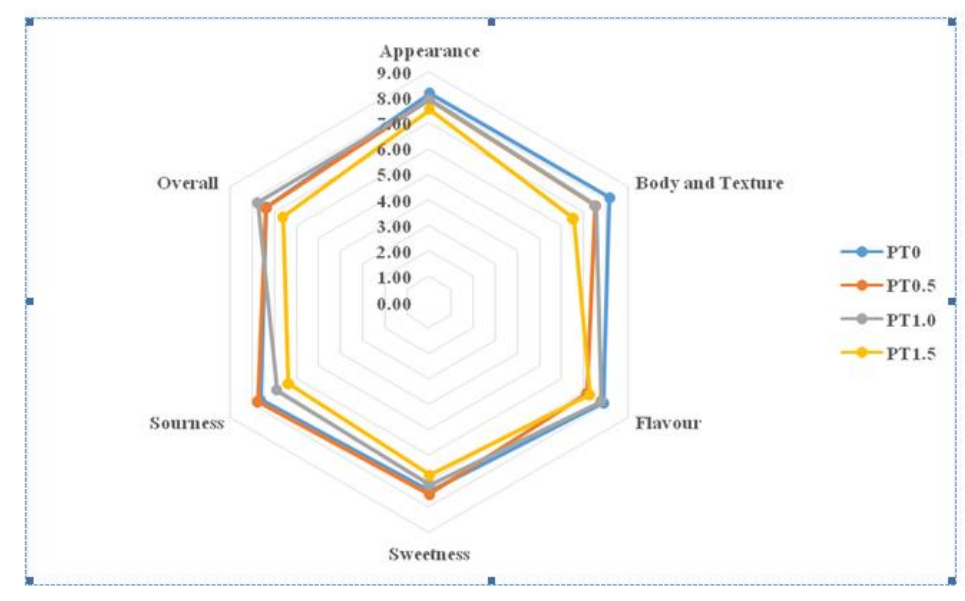




\section{Titratable acidity}

The titratable acidity of the fortified drinkable yoghurt with grape pomace variants at different inclusion levels increased as the concentration of treatments increased. This may be due to fermentation process of carbohydrate inside the milk (lactose) by lactic acid bacteria to produce lactic acid. Increase in titratable acidity is trailed by decrease in $\mathrm{pH}$. This was in accordance with Agustini et al. (2017) who enriched yoghurt with Spirulina platensis powder.

pH

In this study, it was found that $\mathrm{pH}$ of the fortified drinkable yoghurt with grape pomace variants at different inclusion levels decreased as the concentration of treatments increased, because the $\mathrm{pH}$ value of pomace grape flour was 3.82 (Sousa et al. 2014). Similar results were found when fortifying drinking yogurt with dried apple peel powder Zhou, Z. (2018).

\section{Total solids}

Total solids content of drinkable yoghurt fortified with grape pomace powder increased as the treatment concentration increases whereas no significant change was observed in drinkable yoghurt fortified with ethanol and aqueous grape pomace extract. This is due to higher content of total solids. This was in agreement with the results published for yoghurt enriched with grape juice (Hossain et al.2012) and pineapple juice Gangwar et al. (2016).

\section{Viscosity}

Viscosity of grape pomace variants enriched drinkable yoghurt increased as the concentration increases; this might be due to the fact that the total dietary fiber content of grape pomace is higher. Similar study has been carried out for drinking yoghurt enriched with dried apple peel powder (Zhou, 2018).

\section{Fat}

In this study, it was found that fat content of the fortified drinkable yoghurt with grape pomace variants at different inclusion levels increased as the concentration of treatments increased, due to high fat content in pomace grape flour (Sousa et al. 2014). Similar results were reported by Maurya (2016) who examined fat content of guava seed powder fortified yoghurt.

\section{Total dietary fibre}

In this study, it was found that total dietary fibre content of the fortified drinkable yoghurt with grape pomace variants at different inclusion levels increased as the concentration of treatments increased, due to high total dietary fibre content in pomace grape flour (Sousa et al., 2014). The present study was found complementary to the report of Mohamed et al., (2014) who reported similar trend in yoghurt fortified with dietary fibre and phenolic compounds.

\section{Sensory evaluation}

In grape pomace powder fortified drinkable yoghurt, sensory attributes such as appearance, body and texture, flavor, sweetness, sourness and overall acceptability among the control, $0.5,1.0$ and 1.5 per cent scores reduced as the concentration of grape pomace powder increases. The scores for sensory attributes of $1.0 \%$ grape pomace powder fortified drinkable yoghurt were found to have scored the highest among the different treatments as shown in Figure 2. Some panelists indicated their appreciation on the nutritional value and fruity taste of grape pomace powder fortified yogurt, but others stated their disliking on the chalky and medicinal after taste which might come from the astringency of tannin in grape pomace. 
The results were in conformity with studies by Tseng and Zhao, (2012) who studied Wine grape pomace as antioxidant dietary fibre for enhancing nutritional value and improving storability of yogurt and salad dressing.

Hence concluded in this study, grape pomace powder fortified drinkable yoghurt with $1.0 \%$ level was accepted by the panelists. Dairy products are deficient in Dietary fiber, addition of grape pomace powder enriched dietary fiber content could be potentially considered as a source of ingredient for drinkable yoghurt supplementation. Thus the by-product obtained from grape juice could be utilized as a raw material for the preparation of drinkable yoghurt.

\section{References}

Agustini, T. W., Soetrisnanto, D., and Ma'ruf, W. F. (2017). Study on chemical, physical, microbiological and sensory of yoghurt enriched by Spirulina platensis. International Food Research Journal, 24(1).

AOAC. (1990). Official methods of analysis, 16th edition. Gaithersburg, Maryland, USA. Association of Official Analytical Chemists - AOAC. Official methods of analysis. 17th ed. Maryland: AOAC, 2007.

De, S. (1980). Outlines of Dairy Technology. Oxford University Press, Delhi. pp. 216.

Gangwar. R, Hai. H.A, Kumar.P, Sharma N.K. (2016). Development and Quality Evaluation of Yoghurt Fortified with Pineapple, Apple and Sweet Lemon Juice (Fruit Yoghurt). International Journal of Engineering Research \& Technology., 5(3), 621-629.

Ghosh, D., Chakraborty, C., and Dasgupta, R. (2017). A Survey on Indian Grapes at Sangli, Maharashtra, India. Int. J. Curr. Microbiol. App. Sci, 6(5), 1904-1911.
Hossain, M. N., Fakruddin, M., and Islam, M. N. (2012). Development of Fruit Dahi (Yoghurt) Fortified with Strawberry, Orange and Grapes Juice. Am J Food Technol, 7, 562-570.

Larmond, E. (1977). Laboratory Methods for Sensory Evaluation of Foods. Canada Department of Agriculture, Pub., 1637.

Maurya, A. K. (2016). Development of dietary fibre rich yoghurt and biscuits using guava seed powder (Doctoral dissertation, Institute of Agricultural Sciences, Banaras Hindu University).

Mohamed, A. G., Zayan, A. F., and Shahein, N. M. (2014). Physiochemical and sensory evaluation of yoghurt fortified with dietary fiber and phenolic compounds. Life Sci J, 11, 816-822.

Ranganna, S., 1986. Manual of Analysis of Fruit and Vegetable Products. Tata McGraw Hill Publishing Company Ltd. New Delhi. pp. 712 and 109.

Snedecor, G. W and W. G. Cochran. (1994). Statistical methods. Eighth edition, IOWA State University Press, USA.

Sousa, E. C., Uchôa-Thomaz, A. M. A., Carioca, J. O. B., Morais, S. M. D., Lima, A. D., Martins, C. G., and Silva, J. D. N. (2014). Chemical composition and bioactive compounds of grape pomace (Vitisvinifera L.), Benitaka variety, grown in the semiarid region of Northeast Brazil. Food Science and Technology (Campinas), 34(1), 135-142.

Tseng, A., and Zhao, Y. (2013). Wine grape pomace as antioxidant dietary fibre for enhancing nutritional value and improving storability of yogurt and salad dressing. Food chemistry, 138(1), 356-365.

Zhou, Z. (2018). Effects of dried apple peel powder on the rheological and sensory properties of drinking yogurt (Doctoral dissertation).

\section{How to cite this article:}

Subhashini, S., D. Baskaran, B. Dhanalakshmi, B. Murugan and Ayyavoo Preamnath Manoharan. 2018. Physico-chemical Properties of Grape (Vitis vinifera L.) Pomace Fortified Drinkable Yoghurt. Int.J.Curr.Microbiol.App.Sci. 7(05): 2875-2880.

doi: https://doi.org/10.20546/ijcmas.2018.705.335 